\title{
American Engineering Doctoral Enrollments
}

\author{
RICHARD A. SKINNER
}

Richard A. Skinner is senior consultant to the higher education executive search firm, Harris Search Associates. E-mail: rick@harrisandassociates.com.

The reliance of American engineering doctoral programs on foreign students, especially those from India, is a case in point. US immigration policy changes in 1965 launched a steady and growing stream of Asian students enrolling in American universities-with engineering the second-most enrolled field. Moreover, foreign student numbers have increased dramatically in doctoral programs. By 2006, foreign students on temporary resident visas earned 64 percent of engineering degrees, and many remained in the United States, often as professors. In the latter case, these faculty made it possible for engineering enrollments at both undergraduate and graduates levels to grow to a 20-year high by 2010. Whether that upward trend can continue is more problematic.

\section{The NeEd for Greater CAPACITY}

In recent years, the top-ranked engineering programs in America have increased the numbers of undergraduates and are usually successful in filling master's level programs. Doctoral programs, however, are seldom filled to capacity. The result is a case of the proverbial chicken-or-egg dilemma: more faculty are 
needed to teach larger numbers of engineering students and thereby increase the numbers of doctoral students.

A shortage of doctoral students means that increases in engineering graduates will be harder to acquire, and thus there will be fewer domestic engineering graduates to pursue doctoral studies. Foreign students come to America to pursue graduate degrees more so than undergraduate ones. Foreign students earned 24 percent of science and engineering master's, 33 percent of science and engineering doctorates, and only 4 percent of bachelor's degrees in 2007. But foreign students made up only 3.5 percent of total US enrollments in $2010 / 11$.

Moreover, Indian immigration-a major source of engineering doctoral students-is likely to continue to flow based on the persistent gap in personal income between the two countries and could accelerate, with the large increase in India in the 16-to-34-age group in the future.

\section{GroWing ENGINEERING ENROLLMENTS}

In the near term, American engineering schools should continue to rely on international students to enroll and complete the PhD. Most signs are that such reliance is a reasonable strategy, but only for the near term. Demographic trends in India signify increases in the number of qualified students from India who can seek admission to US doctoral programs. Moreover, Indian research universities have not advanced as rapidly as their Chinese counterparts; so, American institutions will remain attractive for Indians to do doctoral work, particularly since English is a common language. 
In addition, the US immigration policy gives preference for reuniting families and 40 percent of Indians immigrated to America, after 2000. Indian immigrants in sizable numbers are likely to continue to come and enroll in a variety of professional fields, including engineering doctoral studies. In 2010 more than 60 percent of Indian science and engineering doctoral recipients reported plans to stay in the United States Beyond the near-term, however, some data suggest that reliance on international students may not be reliable in a more distant future. The National Science Foundation reported that in the first decade of the century the percentage decreased of Asian students reporting plans to remain in the United States. As well, if the economies of China, South Korea, Taiwan, and especially India improve from the global recession of recent years, then foreign students' numbers may decline further as opportunities at home improve.

Midterm prospects for increasing enrollments in doctoral engineering programs depend on persuading graduates to pursue the $\mathrm{PhD}$ and the financial support available for doctoral students-both domestic and foreign. Prospects for persuasion's success are not always successful, so American PhD programs will likely need to recruit international students. That, in turn, will necessitate changes to immigration policy. Such procedures gained a champion in the Partnership for a New American Economy, a coalition of city mayors and corporate heads chaired by chief executive officers from Microsoft and Boeing and New York Mayor Bloomberg, among others.

The Partnership for a New American Economy, as one of the organization's key principles, has increazed "opportunities for immigrants to enter the United States workforce-and for foreign students to stay in the United 
States to work — so that we can attract and keep the best, the brightest, and the hardest-working, who will strengthen our economy." Federal immigration law will need to focus more on facilitating entry and residence by educated individuals interested in graduate studies and engineering-related entrepreneurship, rather than the current preference for reuniting families.

\section{LONG-TERM Prospects}

In the long-term, the immigration of foreign students to America for graduate education may well decline, as income differentials between American and foreign professions narrow and weaken the economic incentive for immigration. Improvement in other countries' universities—especially research-intensive ones, coupled with the demands for faculty in home countries-could strengthen the case for remaining home and foregoing immigration. Only India will require an additional 1 million professors by 2020 .

American doctoral engineering programs' reliance on international students in general and Indian students, in particular, illustrates how one-sided the flow of talent can become over time. Had foreign students not immigrated to the United States in sizable numbers beginning in the mid-1960s, pursued engineering $\mathrm{PhDs}$ and then remained, it is hard to imagine how the field could have grown and contributed so substantially-to endeavors such as the American space program, advances in computing, and improvements in the use of energy.

However, whether similar enterprises will be possible in the future-as at least in part because American engineering programs can be certain of ample 
numbers of well-qualified domestic or foreign students-pursuing the doctorate is problematic. 